mode of transit between Sliema and Valetta, except that he had obseived people performing the journey by that route.

One of your correspondents some time ago gave as an instance of sagacity the case of a monkey returning to him a nut for the obvious purpose of having it cracked. It recalled to me that, several years since, I gave a nut to a monkey in the Zoological Gardens, London, whereupon the said monkey, having put the nut into his mouth and moved his jaws about with a sort of theatrical effect indicative of the hardness of the shell, returned it to me, as any child might have done under similar circumstances, with the evident object of getting me to crack it. I declined, and, at the same time, I gave back the nut. The monkey descended to the ground, laid the nut down, picked up a stone, and at once cracked it for himself, showing an intelligent idea of resources, that as my teeth were not available as a substitute for his, he could utilise a stone for a hammer.

Chas. Popham Miles

Château de St. Léger, Darnétal, Seine Inférieure, October 7

\section{Butterfly Swarms}

INCLOSED is a specimen of butterfly which, about the middle of December, 1878, flew past my bungalow in crowds, all making for north-west, and going down-hill. In about four weeks afterwards, that is, well into January, 1879 , the same butterfly began to return, this time flying to south-east, and uphill. Starting from the bungalow, I rode four miles to north. west, and went about $\mathrm{r}, 000$ feet down-hill, and found the butterfles still ascending. They came from beyond a hill about 300 feet higher than the bungalow, and they went back over the same range.

On both occasions the temperature stood at about $80^{\circ} \mathrm{F}$. in the shade, the winds moderate and variable, and as often against as in favour of the flight, which, on its going and coming, lasted for two to three days both ways.

On the return journey I found the butterflies settled in "swarms" on damp, sandy spots near ravines, and so thickly settled that with one sweep of a circular butterfy net fifteen inches in diameter I canght about ${ }_{5} 5$.

Hill Country of Ceylon, 3,000 feet above Sea-level, September 14

[The butterfly is one of the Pieride, and in all probability is identical with Appias albina, Boisduval. The habit of settling in swarms on damp spots is common to many butterfies, and even to several of the few species that occur in Britain.-ED.]

\section{The Hunting Spider}

THIS arachnid is very common out here, a very tiger amongst in. sects, and very interesting to watch. Its poison must be intensely virulent. If two are placed together under a finger bowl, and one happens to be the smaller, a very little manceuvring soon brings him within the instantaneously fatal grip of the larger animal; but if cf equal size, a most interesting series of watch. ful movements and counter movements commences, each anxious to secure the first and fatal bite. Leap after leap is parried, advance of one is accompanied by a wide awake backward retreat of the other, and so on for a long time. When the fatal spring is made, the victim is at once hors de conbat, and the conqueror carries it off rejoicingly. I once gave a spider a blue-bottle fly, and then learned for the first time that these insects were viviparous, for the fly in its death throes protruded a heap of active little maggots which soon died from want of a proper nidus in which to develop. On another occasion I found a hunting spider on a looking glass, and as from its movements it was evidently after game, I drew near quietly to watch. To my surprise and amusement $I$ found that the spider was stalking its own reflection, and its cautious movements on tip toe, looking downwards, opened up to me a wide field of thought. What feeling was at work in that small breast? Was it the natural instinct after prey, or the burnings of jealousy in the apparent presence of a rival, or pleasure in scrutinising its own charns, now for the first time exhibited to it? If the latter, then the hunting spider is, I fancy, the lowest animal in the scale, which bas been deceived or flattered by a looking.glass.

Dogs, monkeys, and cats, are easily imposed on by a glass, and, as the first thing a monkey does on seeing a mirror, is to pass its hand round to the other monkey, you can soon originate a fight by grasping the hand behind the glass; and then hastily dropping it, watch the amazement of Jacko at the sudden and mysterious disappearance of his rival.

Peshawar

H. F. Hutchinson

\section{GEOGRAPHICAL NOTES}

ON Saturday evening the Berlin Geographical Society, presided over by Dr. Nachtigal, celebrated the birthday anniversary of Carl Ritter, the famous German geographer-a ceremony which had been postponed from August. Ritter himself founded this society in 1828 , and presided over it till I860. "Those days," said Dr. Nachtigal, in opening the proceedings, "on which their intellectual princes are presented to the nations are landmarks of their life and development, and to honour them is a duty of honour." The University, the Army, and the other kindred societies throughout Germany, were all largely represented, and handsome subscriptions were announced for a memorial to the hero of the evening.

Amongst the resolutions passed at the Brussels International Congress for Commercial Geography we point out the following : - I. The Congress is of opinion that, in the interest of all nations it is desirable that one or more lines of railway should connect the coasts of Afric with its interior, 2. Complete freedom of trade should reign there. 3 . In the expectation of a complete abolition of custom-houses, it is desirable that as many commercial treaties as possible should be concluded. It is particularly necessary that a treaty of this kind should be preliminarily entered into between Belgium and Holland. 4. The Congress expresses the wish that everywhere instruction in history should be separate from that in geography. The Congress expressed some further wishes which related to an expedition for discovering the shortest route from Mandalay to Mekong; the speedy execution of the Panama Canal project, the rendering safe of the commercial routes leading to Inner Africa, the furtherance of free trade, the amelioration of the system of representation of countries by consuls, the commercial route from Tong King to the south-west of China, the introduction of the same meridian for all countries, the construction of railways on the Balkan peninsula and in Asia Minor, the introduction of a uniform system of measures, weights, and moneys for all civilised peoples, the abolition of slavery in countries where it continues to be officially countenanced. Next year's congress will take place at Lisbon.

AN International Geographical Congress will be held at Nancy in August, 1880 .

THE International Congress of Americanists was opened at Brussels on September 23. The King of the Belgians and many persons of rank were present.

THE boundary between British Guiana and Venezuela is a very vexed question, and in consequence of Mr. Boddam-Whetham having included in his recent work some notes on it from a Venezuelan source, Mr. E. F. im Thurn, a well-known authority on matters relating to British Guiana, has gone carefully into the matter. $\mathrm{He}$ has just embodied the results of his investigations in a little brochure, which contains a good deal of geographical information. Mr. im Thurn regards the following as the best settlement of the question. The mouth of the Morooca should be taken as the northernmost point of our colony, and from there to the old Dutch post on the Cuyani, the boundary should be as in Cordazzi's map. Thence it should be carried to the nearest point of the Mazaruni, and then up the course of that river to the junction of the River Cako, and along the latter river to Mt. Roraima. From that central and well-marked point, southward to the source of the Corentyne, and then northward along the course of the river, it should follow the line laid down in Sir R. Schomburgh's map. 
THE special service officers, whose departure for South Africa was alluded to in NATURE, vol. xx. p. 64, have evidently done good work from a geographical point of view, for in his despatch, written from Ulundi on September 3, Sir Garnet Wolseley, in reporting the conclusion of the war, states that he has been able to extend our topographical knowledge of Zululand, and by actual survey, as well as by reconnaissances, to lay down on paper with very tolerable accuracy its rivers, mountains, \&c.

THE St. Petersburg correspondent of the Daily News telegraphs that after the departure for England of the seven steamers which failed to get through the Kara Sea, the steamship Louısa, with a Russian charter, succeeded in finding a passage, and arrived at Yeniseisk, discharged her cargo, and loaded 20,000 poods of wheat for Europe. The Golos recommends the establishment of a meteorological station at the extremity of the Island of Waigatz, between the two gulfs, to be connected by telegraph with the other parts of the Empire and Europe.

ACCORDING to the Colonies and India, Mr. Alex. F orrest, in his journey across North.west Australia, from De Grey River to Beagle Bay, found large tracts of rich land along nearly the whole coast and within easy reach of the sea. From Beagle Bay he went to the western shore of King's Sound, and after passing up the Fitzroy River, returned along the eastern boundary of West Australia. He reports well-watered and grass country near Beagle Bay, though it is rather dersely wooded with the cajeput, red and white gum, \&c. No rivers of any size were cliscovered, and the country was almost entirely level. As regards natural productions, Mr. Forrest reports the pearl-shell beds to be unlimited in extent. The soil is generally a sandy loam; in some parts there are a few monstone hills, and in others limestone is found, but nowhere are there any indications of gold.

Mr. ORVILle A. DERBY, Director of Geology in the National Museum of Brazil, we learn from Srience News, was at last accounts about starting on an exploring expedition in the interior of the empire. He goes in company with a party of engineers who are to make surveys for a railroad route. The chief of this party is Mr. Roberts, an American. They will first ascend the river São Francisco to the Falls, which are 168 miles from the sea. They carry with them a steam launch, by means of which they expect to navigate the river above the Falls. Mr. Derby expects to leave the engineers after their work is finished, and to cross the province of Minas Geraes, celebrated for its product of gold, and he will make the geology of that region a special study. The distance to be gone over is not less than 600 or 700 miles, and will probably be much more in the detours of travel. A very hasty geological survey was made of the country in 1866 by J. A. Allen, the ornithologist, O. H. St. John, geologist, and Thomas Ward; they were then members of the famous Agassiz expedition. They began in the upper waters of the river and worked downward toward the Falls. The late Prof. Hartt explored below the Falls, to the mouth of the river. The work undertaken by $\mathrm{Mr}$. Derby is in an important and very extensive field, about which very little is definitely known.

THE American expedition, gone out in search of the remains of Sir John Franklin, which landed at the northern shore of Hudson's Bay, in the vicinity of Depots Land, on August 9, 1878, continued its journey to King Williams Land in sledges, on April $r, 1879$.

THE German geographers, Drs. Greef and Gasser, have arrived at Lisbon on their way to Africa. A scientific task has been confided to them, and they will begin their labours with the study of the zoology of the West African Islands.

NEws just arrived from Pekin states that the Hungarian traveller, Count Szechenyi and his companions have started on the journey to Tibet, under protection of Chinese officials, and with an escort of thirty soldiers. They intend to visit Sining, Shen-Chung-Chia, and Tsaidam, and then to proceed on the great northern Kukunor road to H'Lassa, which is situated some 700 miles beyond Tsaidam.

EARLY in the present year the Rev. C. R. Fairey made a most remarkable missionary journey, travelling alone for some 300 miles along the dangerous north and east coasts of Tasmania. The journey was entirely performed in a canoe 12 feet long, 28 inches beam, and 12 inches in depth. Mr. Fairey now proposes to make a voyage on the Murrumbidgee and Murray Rivers in Australia.

AFTER the pattern of European Alpine Clubs a Himalaya Club is stated to have been formed in India with a view of attempting to ascend the highest peaks of that gigantic mountain chain.

UNDER the title of "La Cimbébasie" Les Missions Catholiques publishes some interesting geographical notes on a tract of country in Western Africa, extending on the seaboard from the mouth of the River Cunene to that of the Orange River. On the north the boundary of this region, which has lately been constituted a separate ecclesiastical district by the Holy See, marches with that of the Portuguese colony of Angola in the direction of the Mano Mountains, and then follows the right banks of the Casai and the Lotenbua as far as Lake Dilolo. On the east it runs along the Liba to the point where the Chobé (the Cuando of Major Serpa Pinto) falls into the Zambesi, and finally follows the eastern frontier of the Bechuanas from Lake Makarikari to the Rivers Vaal and Orange. In this region are included Damara-land on the north-west, Namaqua-land on the south, the tribes of the Kalahari Desert on the east, and on the north Ovampo-land, \&c. These notes, which are drawn up by Père Charles Duparquet and are illustrated by a map, are the more worthy of attention, as the greater part of this large tract of country has recently been placed under the British Protectorate.

SIR GEORGE ELLIOT, M.P. for North Durham, has signified his intention to dedicate a piece of land on his estate, West Cliff, Whitby, to the public, and erect thereon a monument to Capt. Cook, who spent several years of his early life at the fishing village of Staithes, a few miles to the north of the port of Whitby. In later years be sailed from the harbour of Whitby, and it is an historical fact that in undertaking his adventurous voyages round the world he preferred the vessels which were built at Whitby by Whitby men.

MESSRS. SAMPSON LOW AND Co. are to publish Dr. Holub's Narrative of his important explorations in South Africa, They have also in the press Signor D'Albertis' Narrative of his Explorations in New Guinea; it will contain many illustrations in ethnography and natural history.

THE last Zeitschrift of the Berlin Geographical Society contains detailed narratives by Dr. Hildebrandt of his important journey from Mombassa to Kitur, and by Dr. Hirschfeld of a journey he made in South-West Asia Minor. The Verhandlungen contains a valuable description of the Galapagos Islands, by Dr. Theodor Wolf, and a series of measurements of elevations in Ecuador, by the same, both from the Spanish of W. Reiss.

From the American Geographical Society we have received the annual address of the president, Dr. C. P: Daly, being an elaborate and valuable paper on the Early History of Cartography, or, "Maps and Map-Making before the time of Mercator." The paper is profusely illustrated with specimens of old maps, and must have involved a great amount of research. The last Bulletin of the Society (No. 5 of 1878 ) contains a long account of a journey along the west coast of South America, from 
Panama to Valparaiso, by Mr. James Douglas, and an account of a visit to the "Wonderful Rivers of Cambodia," by Mr. Frank Vincent.

DR. CRevauX, the explorer of French Guiana, is not yet, it seems, coming home, but will attempt to reach the Andes by the Iça or Putumayo, exploring that watersystem as he has already done the Marori, Ozapok, Yary, and Para.

\section{OUR ASTKONOMICAL COLUMN}

BIELA'S COMET.--Even if the earth should encounter an unusual number of meteors on arriving at the descending-node of Biela's comet next month, as some have anticipated, the display is likely to be masked to a considerable extent by overpowering moonlight. The earth will reach the node (so far as we can judge of its actual position) on November 27 , and the moon will be full on the following day. Remembering that the meteors of 1872 were not generally remarkable for brightness, though there were some notable exceptions, should there be a return of the shower, a large proportion may escape notice. No doubt, however, a strict watch will be maintained during the last week in November. We are not able to judge how near we may be to the meteoric mass which the earth met on November 27,1872 ; it would arrive at perihelion at the end of December in that year, but we do not know the exact period in which it was revolving.

It is worthy of note that the effect of the differences of mean anomalies and mean motions when the two nuclei of the comet were last observed in $\mathrm{5} 852$, would in 1879 occasion a difference in the times of perihelion passage to the extent of nearly $3 \frac{1}{2}$ days, and the mutual distance of the nuclei would be increased to 0.075 of the earth's mean distance from the sun, or nearly 7,000,000 miles.

Between the year 1772 , when the comet was first observed, and 1852, when the last observations were obtained, the node had retrograded upwards of $\mathrm{II}^{\circ}$, the perturbation being chiefly caused by tho planet Jupiter in 1794,1831 , and 1842 .

When we consider the conditions under which Biela's comet appeared in 1805 , we are struck with the favourable opportunity which the repetition of such a case may afford for a precise determination of the solar parallax. On the evening of December 8 in that year the come at transit at Greenwich was distant from the earth less than 0.038 , and its horizontal parallax was upwards of four minutes; at this time, with a declination of near $24^{\circ}$ south, it was rapidly descending below the borizon in Europe, still it was well observable, and of course would have been in a very good position for observation at the Cape of Good Hope. Its appearance also was favourable for accurate observations, which is more than can be said of all comets that have approached near to the earth. Olbers mentions that on this evening when he was observing with Bessel, the nucleus was very small and defined like a planet, and Gauss at the same time compares it to a star of the third or fourth magnitude. There has been no such opportunity since the Cape Observatory was established.

\section{THE GALLERIES OF THE CUTTING ANTS OF TEXAS}

N R. McCOOK, the devoted student of insects, has in 1 preparation a memoir, which will be looked for with the intensest interest, resulting from his prolonged investigations into the life-history of the cutting or "parasol" ants of Texas (Atta fervens), bidding fair to rival his work upon the agricultural ants.

First, let us take with Mr. McCook a brief view of a denuded surface on a high grassy prairie, covered with a number of small moundlets of fresh earth-pellets, yet without a sign of life, and looking entirely abandoned; over its surface were seen little heaps of dry twigs and pieces of leaves. But towards evening, hosts of ants hurried out, and formed two long double columns to the top of an overhanging live-oak. The ants in the descending columns all carried above their heads portions of green leaves, whence they derive their popular name of "parasol" ants. The closing of the gates in the morning came to pass thus:-Bits of dry twigs and leaves of various lengths are carried into the gallery, filling it up from half an inch to an inch and a half below the surface; often the galleries slant inwards, even to $45^{\circ}$; or divide soon. The larger "castes" carry in the refuse; as the hole closes the smaller castes appear. The "minims," in small squads, fill in all interstices with minute grains of sand, and finally the last steals in behind some bit of leaf, and the establishment is closed. The reverse takes place, when outside work is resumed in the evening. When the larger forms get out they at first carry away and drop their burdens, and little seems to be accomplished for a long time. But in a marvellous way there occurs a final rush, by which the gate is opened. The bigger pieces of twigs are evidently regarded as special treasures, and were seen used on several successive days. The use of the smallest castes is thus found; some remain at only one-sixteenth of an inch long, while the fertile female attains nearly an inch, and the male is three-fourths of an inch long. The interior of the formicary is composed of caverns or pockets communicating with the surface and with each other by tubular galleries. The chambers contained masses of very delicate leaf-paper wrought into rude combs. Some masses were hemispheres in shape, others were arranged in columns two and a half inches high, in contact, along the floor of the chambers, whose dimensions might be nearly three feet by one foot, and eight inches high. Some hung from tree-roots which passed through the chamber. All this material was composed of the fibre of leaves reduced to this form within the nest. In each portion of ant-comb the cells were nearly hexagonal, but very varied in size, some being half an inch in diameter, but most of them as minute as one-eighth of an inch. Large circular openings ran into the heart of the mass. Ants of the small castes were very numerous in these cells. The material of the comb was very fragile and perishable. It is supposed by $\mathrm{Mr}$. McCook that the ants feed upon the juices of the leaves, but this waits further confirmation. Some of these chambers are even of very large dimensions; one of the size of a flour-barrel was seen, being the main cavity of a formicary, in which were found very many winged males and females and larvæ. This was situated 669 feet from a tree that stood in the front yard of a house, which these ants had stripped. Mr. McCook took a plan of the underground way traversed by the ants to reach this point ; the course varied very little from a straight line; two branches had been made to a peach orchard 120 feet distant. Only the small forms appear to take part in the digging, while the larger assist in opening the gates, make the excursions, and do the leaf cutting. The least forms, or minims, assist in opening and closing doors, and taking charge of larvæ. The minims are quite ferocious in attack, and gallantly support the large-headed soldiers. The process of leaf-cutting has been so successfully observed by Mr. McCook, that it is quite deserving of further notice, which we hope soon to give.

\section{G. T. BETTANY}

\section{ROUTES TO CHINA via ASAM}

THE possibility of connecting India with China by a tolerably direct and easy trade route overland is a question of increasing interest to us all, in India and England. Not only would such a route benefit the large valley of Asam, by causing an influx of labour more or 